\title{
Method for reduction of pesticide residue levels in raspberry and blackcurrant based on utilization of ozone
}

\author{
Wykorzystanie ozonu do obniżania poziomu pozostałości \\ pestycydów w malinach oraz czarnej porzeczce
}

\begin{abstract}
* Dr inż. Maciej Balawejder, mgr Piotr Antos, dr inż. Radosław Józefczyk, Faculty of Biology and Agriculture, University of Rzeszów, Ćwiklińskiej 1 St., 33-601 Rzeszów, Poland, phone: +48 17 8721745, e mail: maciejb@ univ.rzeszow.pl

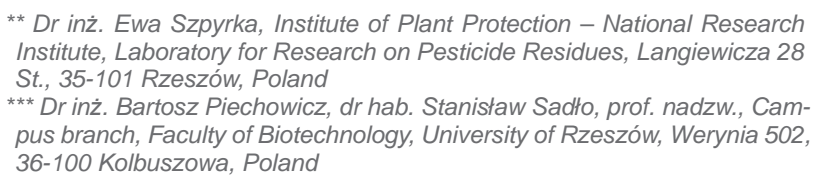

** Dr inż. Ewa Szpyrka, Institute of Plant Protection - National Research Institute, Laboratory for Research on Pesticide Residues, Langiewicza 28 St., 35-101 Rzeszów, Poland

*** Dr inż. Bartosz Piechowicz, dr hab. Stanisław Sadło, prof. nadzw., Campus branch, Faculty of Biotechnology, University of Rzeszów, Werynia 502, 36-100 Kolbuszowa, Poland

Keywords: pesticide residues, raspberry, currant, ozone

Słowa kluczowe: pozostałości pestycydów, maliny, porzeczka, ozon

\section{Abstract}

The method for the reduction of pesticide residues in soft fruits based on utilization of ozone was proposed. The procedure allows for effective reduction of boscalid residues by $38 \%$ in raspberries, and about 58\% thiram in blackcurrants. Furthermore, it can be used on an industrial scale.

(C)IÓ́-PIB

\section{INTRODUCTION}

One of the most important problems in the plant production is the protection of plants from pathogens and pests. Despite the application of modern plant protection products in accordance with Good Agricultural Practice standards, it is nearly impossible to find any samples of some fruits (apple, raspberry and blackcurrant) without residues of their active ingredients [Nowacka et al. 2009]. The utilization of cold storage can preserve the initial fruit quality for months; however, during the storage of plant material, the residues of active ingredients of pesticides that were utilized for protective measures degrade very slowly [Holland et al. 1994; Balawejder et al. 2013]. The aim of this study was to investigate the possibility of removing some pesticides contamination of raspberry dessert with gaseous ozone and confirm dithiocarbamates susceptibility to degradation under the influence of ozone.

\section{MATERIALS AND METHODS}

Chemicals utilized were supplied by local producers: potassium iodide $(\mathrm{KI})$ and methylene blue both p.a. were supplied by Chempur (Piekary Śląskie, Poland) and tin(II) chloride $\left(\mathrm{SnCl}_{2}\right)$ p.a. was supplied by $\mathrm{POCH}$ S.A. (Gliwice, Poland); acetone p.a. (Gliwice, Poland); petroleum ether p.a. (Gliwice, Poland); Florisil ${ }^{\circledR}$ 60-100 mesh, Fluka (St. Louis, USA); sodium sulphate(VI) p.a. (Gliwice, Poland); magnesium sulphate (VI) p.a. (Gliwice, Poland).

\section{Streszczenie}

Została przedstawiona metoda redukcji pozostałości pestycydów w owocach miękkich z wykorzystaniem ozonu. Zastosowana procedura pozwala na skuteczne obniżenie pozostałości boskalidu o 38\% w malinach, o 58\% tiuramu w czarnej porzeczce. Ponadto, może być wykorzystywana na skalę przemysłowa.

2.1. The origin of the raspberry and scheme pesticides spraying

Samples of Rubus L. (strain Laszka) were collected from a raspberry plantation localized in proximity of Kraśnik, a small town in southeastern Poland. The plantation covers an area of approximately 0.46 hectares. Fruits were collected randomly across the surface of the plantation. Overall, a $20-\mathrm{kg}$ sample of plant material was collected. Then, out of this population several laboratory samples were prepared. They were investigated and the initial levels of pesticides residues were determined. Other samples of raspberry fruits were then exposed to detoxification procedure based on utilization of ozone. A similar procedure was utilized to investigate the chances for the reduction of pesticide residues on the leaves of raspberry. For this purpose, a sample of $3 \mathrm{~kg}$ of leaves was collected.

Pesticides spraying was performed according to the dosages recommended by manufacturers in comply with the labels of individual receptures. Dates of applications, active ingredients and the names of each plant protection product utilized are presented as follows: 15.05 Chlorpyrifos DURSBAN 480 EC, 20.05 folpet FOLPAN 80 WG, 01.06 tetrakonazol DOMARK 100 EC, 10.06 pyrimethanil MYTHOS 300 SC, 17.06 pyraclostrobin, boskalid BELLIS 38 WG, 21.06 pirimicarb PIRIMOR 500 WG, 24.06 cypermethrin CYPERKILL SUPER 250 EC, 25.06 cyprodinil UNIX 70 WG, 28.06 piraklostrobina and boskalid SIGNUM 33 WG. 
2.2. The origin of the blackcurrant and scheme of pesticides spraying

Samples of Ribes nigrum L. (strain Ojebyn) were collected from two blackcurrant plantations localized in proximity of Kraśnik. The plantations covered an area of approximately 0.5 hectares per plantation. Fruits were collected randomly across the surface of each plantation. Overall, a $20-\mathrm{kg}$ sample of plant material was collected. A portion of blackcurrant fruits was then exposed to detoxification procedure based on utilization of ozone.

Pesticides spraying was conducted three times. The first allocation was done in April and the following applications were done in 14-day intervals. Product that was utilized for the protective measures was TIURAM GRANUFLO 80 WG at a dose of $4 \mathrm{~kg} / \mathrm{ha}$.

\subsection{Device utilized in ozonation experiment}

The apparatus for ozone treatment (Fig. 1) consists of the chamber (1), which the inner space is linked via a pipeline (2) and the heater (3) with the pump (4) of the air. Also, the pipeline (2) before the chamber (1) is connected to a pipe supplying ozone (5) with the valve (6). In addition, the pump (4) via a pipe (7) with a three-way valve (8) is connected directly to the chamber (1). Also, the chamber is linked through a pipeline with the valve (8) to an ozone destroyer (9), which is preventing the contamination of the environment by residual ozone. Inside the chamber (1), there is a fan (10), which increases the mass exchange; the inner space of the chamber is coupled with its pressure gauge (11), a thermometer (12) and a sensor of the ozone concentration (13). The inner space is isolated from the environment by a gas-tight door (14). This device was used in combination with the Ozone Solution TS 30 ozone generator, and the ozone concentration was measured by the 106M UV-Ozone Solution detector, with a measuring range of 0-1000 ppm.

\subsection{Ozonation procedure}

A $1000 \mathrm{~g}$ of fruit was placed in individual packaging within a chamber (1). Then, the ozonation process was carried out for
60 min. During the procedure, the ozone concentration was maintained at $16 \mathrm{ppm}$ and the gas flow rate of the ozone-air mixture was $4 \mathrm{~m}^{3} / \mathrm{h}$. After $1 \mathrm{~h}$ of exposure, the mass reduction was found not to exceed $5 \%$; moreover, fruits retained their taste and appearance. A similar procedure was also used for the raspberry leaves. A sample of $300 \mathrm{~g}$ of leaves was placed in the chamber. After the ozonation, there were no major changes in the appearance and the weight reduction was not greater than $10 \%$. Ozonation of blackcurrant was conducted in parallel in aqueous solution of ozone and by gaseous ozone. Ozone bath and the treatment with ozone in gaseous phase coupled with drying process were performed according to the procedure described in Antos et al. [2013] with the exception that the treatment with ozone in gaseous phase coupled with drying process was conducted by means of a apparatus presented in Figure 1.

\subsection{Determination of pesticides residues}

\subsubsection{Extraction of the pesticides residue and GC analysis}

Analytical portions of fruit (approximately $100 \mathrm{~g}$ ) were homogenized for about 2 min with $150 \mathrm{ml}$ of acetone with Waring blender. The homogenate was filtered on a Buchner funnel under vacuum and the filter cake was rinsed with $50 \mathrm{ml}$ of acetone, and after thorough mixing, the filtrate volume was measured. One-fifth of the filtrate was poured into a separatory funnel containing $100 \mathrm{ml}$ of $2.5 \%$ sodium sulphate $(\mathrm{VI})$ and $20 \mathrm{ml}$ of dichloromethane and then shaken vigorously for about $1 \mathrm{~min}$. After separation of the organic phase, the aqueous lower layer was dried with anhydrous sodium sulphate (VI) placed on a glass funnel. The aqueous phase was extracted twice with $10 \mathrm{ml}$ of dichloromethane and the combined extracts were evaporated to dryness on a rotary evaporator. Residues were dissolved in about $10 \mathrm{ml}$ of petroleum ether and loaded into a glass column containing a plug of cotton wool and $1.1 \mathrm{~g}$ of activated florisil and $4.5 \mathrm{~g}$ of anhydrous sulphate $(\mathrm{VI})$ solution. Pesticides were eluted by a mixture of petroleum ether-diethyl ether and then by petroleum

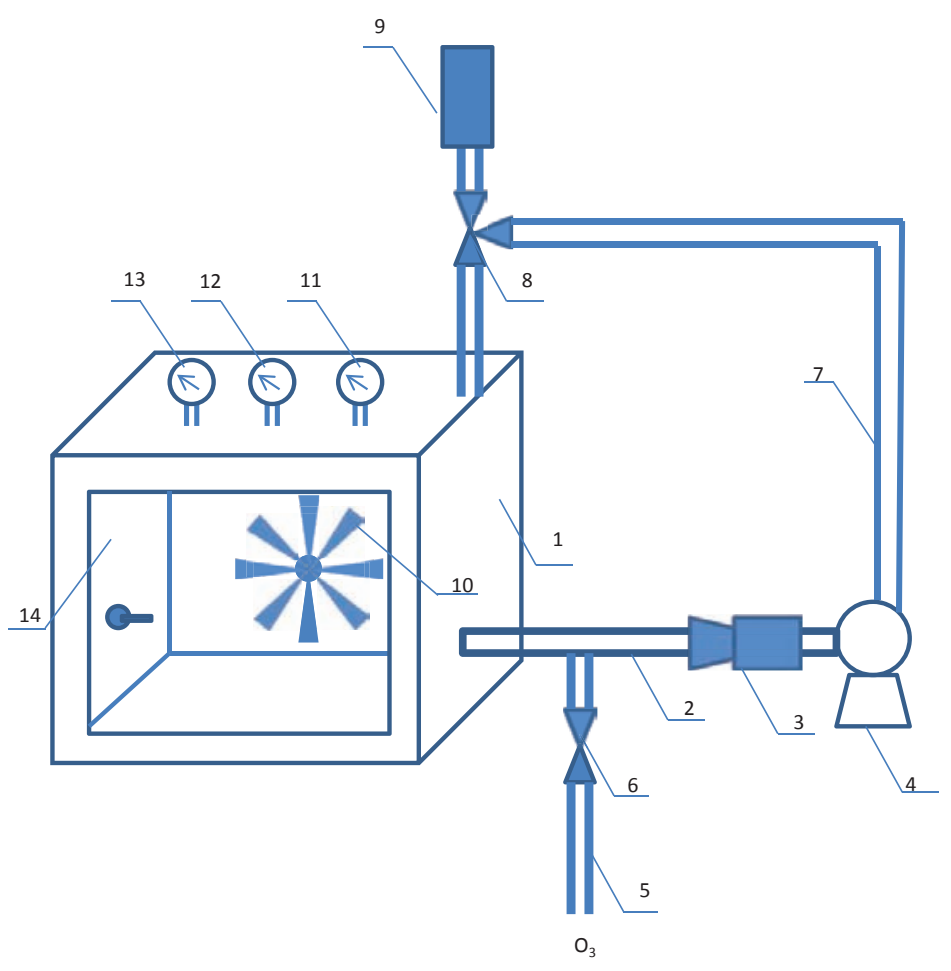

Fig. 1. Scheme of the apparatus used for ozone treatment of fruits [Balawejder et al. 2014a; Balawejder et al. 2014b] 
ether-acetone. Both eluates were evaporated to dryness and residues were dissolved precisely in $10 \mathrm{ml}$ of petroleum ether. Analysis was conducted according to Szpyrka et al. [2013]. The final analytical extracts were analyzed on Agilent (Palo Alto, CA, USA) 7890 gas chromatograph equipped with electron capture and nitrogen phosphorus detectors and fused silica column (HP-5 MS Ultra Inert column, 30-m length, 0.32-mm i.d. and $0.25-\mu \mathrm{m}$ film thickness; Agilent). The temperatures of the injector and detectors amounted accordingly to 250 and $300^{\circ} \mathrm{C}$. The extracts of samples $(2 \mu \mathrm{L})$ were injected in splitless mode. The oven temperature was programmed as follows: $100^{\circ} \mathrm{C}-0 \mathrm{~min}$ $\rightarrow 10^{\circ} \mathrm{C} / \mathrm{min} \rightarrow 180^{\circ} \mathrm{C}-4 \mathrm{~min} \rightarrow 3^{\circ} \mathrm{C} / \mathrm{min} \rightarrow 220^{\circ} \mathrm{C}-15 \mathrm{~min} \rightarrow$ $10^{\circ} \mathrm{C} / \mathrm{min} \rightarrow 260^{\circ} \mathrm{C}-11 \mathrm{~min}$; the total time of the analysis was 55.3 min. Nitrogen (purity 6.0) was the carrier gas for both detectors (flow: $4.14 \mathrm{~mL} \mathrm{~min}^{-1}$ ) and the makeup gas for the ECD (flow: $30 \mathrm{~mL} \mathrm{min-1)}$ ) and NPD (flow: $10 \mathrm{~mL} \mathrm{~min}^{-1}$ ). For the NPD, hydrogen and air flows were kept at 3 and $60 \mathrm{~mL} \mathrm{~min}^{-1}$, respectively. Recovery studies were carried out by spiking analytical portion of blank sample with stock pesticide solutions. Their average values for pyrimethanil, pyraclostrobin, boscalid, chlorpyrifos, cypermethrin, folpet, pirimicarb and cyprodinil were: $93.7 \%, 118.1 \%$, $89.1 \%, 91.9 \%, 85.7 \%, 101.8 \%, 90.2 \%$ and $95.2 \%$ with Relative Standard Deviations not exceeding 10.7\% (pyraclostrobin). The estimated limits of quantifications were $0.001 \mathrm{mg} / \mathrm{kg}$ for chlorpyrifos and $0.005 \mathrm{mg} / \mathrm{kg}$ for other pesticides.

\subsubsection{Determination of thiram residues in fruits of black currant}

Levels of DTC residues in analytical samples have been determined by their decomposition to carbon disulphide $\left(\mathrm{CS}_{2}\right)$ in acidic environment with a presence of $\mathrm{SnCl}_{2}$. After that $\mathrm{CS}_{2}$ was transferred to methylene blue. Finally, the samples were analysed in aqueous solution on Unicam Helios spectrometer at $662 \mathrm{~nm}$ wave length [Chmiel 1979; Sadło et al. 2003]. DTC residues were expressed in $\mathrm{mg}$ of $\mathrm{CS}_{2}$ per $\mathrm{kg}$ of plant material. Recovery of DTC was $100.8 \%$ and limit of quantification was $0.05 \mathrm{mg}$ of $\mathrm{CS}_{2} / \mathrm{kg}$.

\section{RESULTS AND DISCUSSION}

To obtain representative results, three independent experiments were performed. During each experiment, three analytical sam- ples were taken. The obtained results were analysed with a statistical test (test-t) of the significance of the differences between two population means. No differences were found for the pesticide residues in fruits before and after ozonation at the significance level of $\alpha=0.01$ for all active substances except boscalid as presented in Figure 2. The statistical analysis was carried out using MS EXCEL 2010.

It was found that this substance was reduced by over $38 \%$. The remains of this compound were at the highest level, because it was a component of the two preparations such as BELLIS 38 WG and Signum 33 WG, which were used in the protection. Probably, most residues of this compound were present on the surface of fruits, since the spraying with this agent was the latest method executed. The gaseous ozone had the opportunity to decompose the residues present at the fruit surface. Other compounds were either resistant to this oxidant or more likely had enough time to penetrate into the fruit deeply enough that they were beyond the reach of ozone. Similar observations were made during the experiment with leaves, also in this case only the reduction of boscalid by more than $13 \%$ was observed (Fig. 3).

The procedure was also utilized for the reduction of pesticide residues in blackcurrant fruit. Levels of thiram residues from both plantations were determined to be around $0.55 \pm 0.02 \mathrm{mg} \mathrm{CS} / \mathrm{kg}$ for first plantation and $0.4 \pm 0.017 \mathrm{mg} \mathrm{CS} / \mathrm{kg}$ for the second plantation. In accordance with the results of earlier studies on degradation of mancozeb residues [Antos et al. 2013], it was possible to reduce the level of residual thiram both by washing in ozonated water (reduction by 38\%) (Fig. 4a) and using gaseous ozone in combination with drying (reduction by $58 \%$ ) (Fig. 4b).

\section{CONCLUSIONS}

1. Ozone is an effective agent that can be utilized for the reduction of pesticide residues on the fruit surface.

2. It was confirmed that the group of dithiocarbamates fungicides are prone to degradation by ozone.

3. It was found that ozone is a good factor for improving of the state of raspberry fruit and for both fruits and leaves of the raspberry.

4. The proposed method of combining ozonation with drying process can be applied for the reduction of pesticide residues in the plant material.

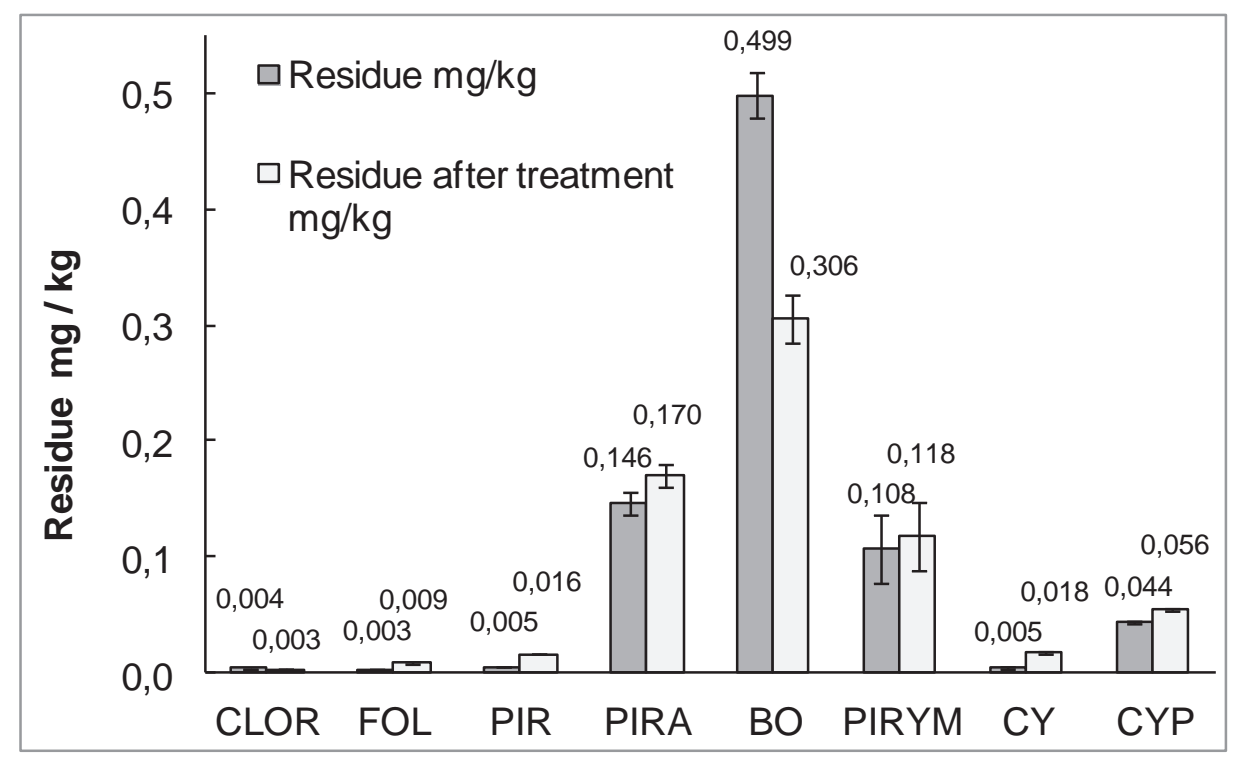

Fig. 2. Residues of chlorpyrifos (CLOR), folpet (FOL), pyrimethanil (PIR), pyraclostrobin (PIRA), boscalid (BO), pirimicarb (PIRYM), cypermethrin (CY) and cyprodinil (CYP) in raspberry before (dark bar) and after ozonation (bright bar) 


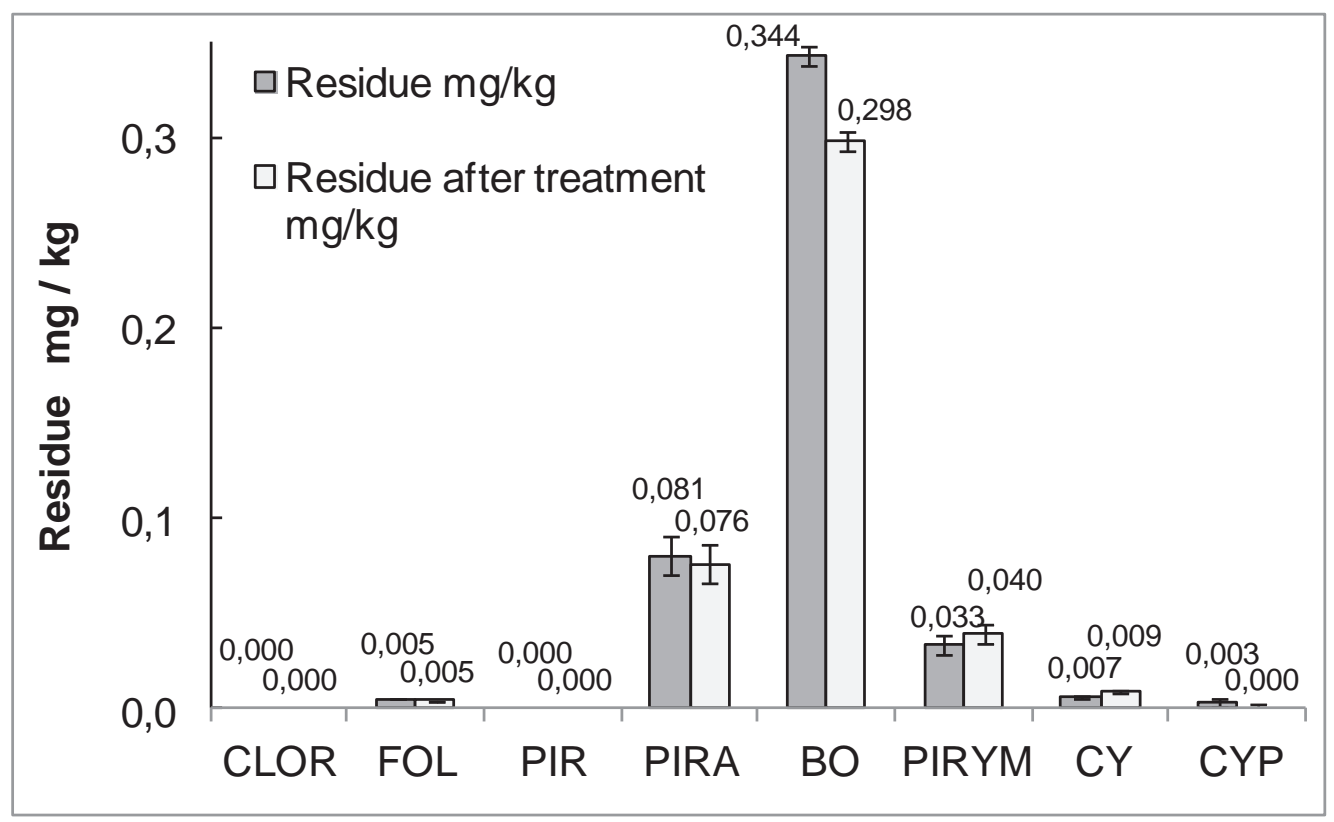

Fig. 3. Residues of chlorpyrifos (CLOR), folpet (FOL), pyrimethanil (PIR), pyraclostrobin (PIRA), boscalid (BO), pirimicarb (PIRYM), cypermethrin (CY) and cyprodinil (CYP) in raspberry leaves before (dark bar) and after ozonation (bright bar)

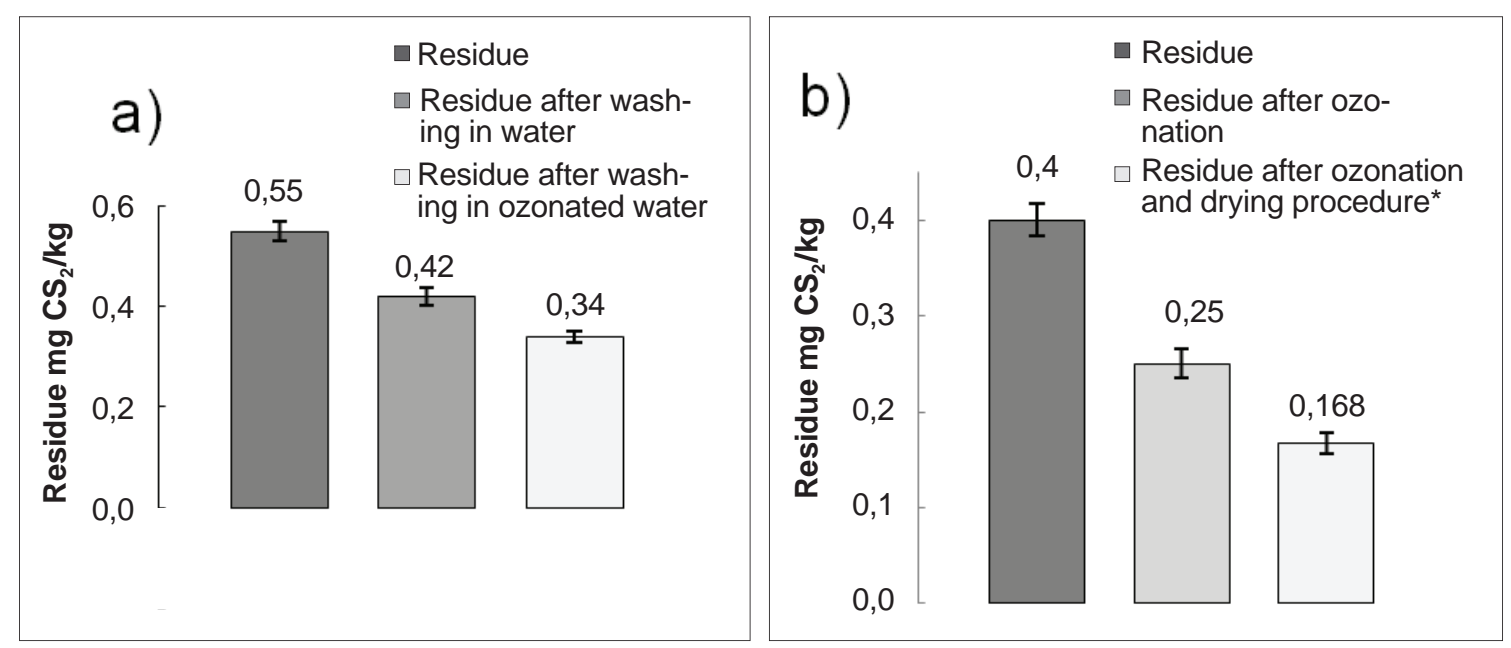

Fig. 4. Detoxification effect on blackcurrant in washing procedure (a) and during ozonation procedure coupled with drying process (b) *The presented values were obtained after the calculation of drying index (DI). DI can be calculated by dividing the initial fruit mass by the fruit mass after water loss. The residue levels in fresh fruits are calculated by the multiplication of residue levels within the dried plant material with DI value.

\section{REFERENCES}

ANTOS P., KURDZIEL A., SADŁO S., BALAWEJDER M. 2013. Preliminary study on the use of ozonation for the degradation of dtithiocarbamate residues in the fruit drying process: mancozeb residues in blackcurrant is the example used. Progress Plant Protection 53 (1): 48-52.

BALAWEJDER M., ANTOS P., SADŁO S. 2013. Potential of ozone utilization for reduction of pesticide residue in food of plant origin. A review, Rocz. Panstw. Zakl. Hig. 64(1): 13-18.

BALAWEJDER M., CHWASZCZ B., ANTOS P., JÓZEFCZYK R. 2014a. Sposób przedłużania trwałości malin w warunkach nie chłodniczych oraz urządzenie do realizacji tego sposobu. Patent application P 407854.

BALAWEJDER M., CHWASZCZ B., ANTOS P., JÓZEFCZYK R., PRZEPIÓRA M. 2014b. Sposób sanitaryzacji oraz obniżenia pozostałości pestycydów w materiale roślinnym w procesie suszenia oraz urządzenie do realizacji tego sposobu. Patent application P 408250.

CHMIEL Z. 1979. Spektrofotometryczne oznaczanie śladowych pozostałości dwutiokarbaminianów w materiale roślinnym. Chem. Anal. 24: 505-511.

HOLLAND P. T., HAMILTON D., OHLIN B., SKIDMORE M. W. 1994. Effects of storage and processing on pesticide residues in plant products. Pure Appl Chem. 66: 335-356.

NOWACKA A, GUSOWSKI B, WALORCZYK S., DROŻDŻYŃSKI D.,WÓJCIK A., RACZKOWSKI M., HOŁDYŃSKA A, BARYLSKA E., ZIÓŁKOWSKI A., CHMIELEWSKA E., RZESZUTKO U., GIZA I., ŁOZOWICKA B., KACZYŃSKI P., RUTKOWSKA E., SZPYRKA E., RUPAR J., ROGOZIŃSKA K., MACHOWSKA A., SŁOWIK-BOROWIEC M., KUŹMENKO A., SZALA J. 2009. Pozostałości środków ochrony roślin 
w płodach rolnych (Rok 2008). Progress Plant Protect. 49: 1903-1917.

SADŁO S., SZPYRKA E., ROGOZIŃSKA K., RUPAR J. 2003. Oznaczanie pozostałości ditiokarbaminianów w owocach i warzywach na poziomie $0,01 \mathrm{mg} / \mathrm{kg}$. [Determination of dithiocarbamate residues in fruit and vegetables at the level of
$0.01 \mathrm{mg} / \mathrm{kg}$ ]. Prog. Plant Protect./Post. Ochr. Roślin 43 (2): 895-897.

SZPYRKA E., KURDZIEL A., MATYASZEK A., PODBIELSKA M., RUPAR J., SŁOWIK-BOROWIEC M. 2013. Pesticide residues in crops from the south- eastern region of Poland (2012), Progress Plant Protect. 53 (2): 402-406. 